\title{
Performance and carcass characteristics of goats fed crude glycerin in the feedlot and during pre-slaughter lairage
}

\author{
Carolina Pilar Alves e Dias ${ }^{1}$, Fredson Vieira e Silva ${ }^{1 *}$, Aylle Medeiros Matos ${ }^{1}$, Laura Lúcia dos \\ Santos Oliveira ${ }^{1}$, Amilton Maia Freitas de Oliveira ${ }^{1}$, Vicente Ribeiro Rocha Júnior ${ }^{1}$ (iD, \\ Leandro Farias Batista ${ }^{1}$, Valéria Dias Martins ${ }^{1}$
}

${ }^{1}$ Universidade Estadual de Montes Claros, Departamento de Ciências Agrárias, Janaúba, MG, Brasil.

\begin{abstract}
This study evaluated the effects of crude glycerin (CG) supplied separately from the other dietary ingredients to goats during the feedlot and in the pre-slaughter lairage on the nutrient intake, performance, behavioral and physiological parameters, carcass characteristics, and meat quality. Twenty-eight uncastrated male goats from a cross between the Boer breed and mixed-breed goats were used in a completely randomized design in a $2 \times 2$ factorial scheme, consisting of the feedlot with or without CG inclusion in the diets $\left(96.90 \mathrm{~g} \mathrm{~kg}^{-1} \mathrm{DM}\right)$ and the pre-slaughter lairage, also with or without the ingredient. In the feedlot, goats fed CG had a lower intake of dry matter and nutrients. Crude glycerin intake reduced the weight gain and body weight of goats and increased feed conversion. Weights of carcass and cuts (leg, loin, ribs, and shoulder) were lower when the animals consumed CG in the feedlot. In pre-slaughter lairage, concentrations of cortisol were lower when the animals consumed CG. Characteristics of carcass and meat ( $\mathrm{pH}$, color, water holding capacity, cooking loss, and shear force) were not changed by the supply of CG during the pre-slaughter. When supplied during the feedlot period and separately from the other dietary ingredients, CG negatively affected the performance and carcass characteristics of goats without changing meat quality. In the pre-slaughter lairage, CG intake lowers the cortisol level and does not change the behavioral parameters or carcass and meat characteristics of goats.
\end{abstract}

Key Words: carcass quality, meat quality, slaughterhouse, welfare

\section{Introduction}

The incentive for biodiesel production as a source of renewable energy has led to the production of large amounts of crude glycerin (CG) (ANP, 2016). Crude glycerin can be used in animal feeding due to its high acceptability and energy value (Donkin et al., 2009; Parsons et al., 2009; Terré et al., 2011; Pellegrin et al., 2012). This compound has been used at different inclusion levels in ruminant feed (intervals of 25 to $550 \mathrm{~g} \mathrm{~kg}^{-1}$ ). When supplied at $100 \mathrm{~g} \mathrm{~kg}^{-1}$ of the dry matter (DM) of diets for feedlot animals in the concentrate or in the water, it does not reduce nutrient intake, performance, or carcass and meat characteristics (Borges et al., 2013; Chanjula et al., 2014a; Silva et al., 2018). In addition to its use in the feeding of animals in feedlot, it is presumed that this feed can serve as a source of energy for pre-slaughter kids.

Received: July 17, 2017

Accepted: December 25, 2017

*Corresponding author: fredson.silva@unimontes.br

Copyright (C) 2018 Sociedade Brasileira de Zootecnia. This is an Open Access article distributed under the terms of the Creative Commons Attribution License (http://creativecommons.org/licenses/by/4.0/), which permits unrestricted use, distribution, and reproduction in any medium, provided the original work is properly cited.
During the pre-slaughter handling, physiological stress and physical exhaustion may promote expenditure of glycogen, which is associated with meat quality (Del Campo, 2016). In the lairage period, Parker et al. (2007) and Egea et al. (2015) used glycerol as a strategy of prophylactic hyperhydration to reduce the energy deficit and for the maintenance of body water as an osmotic agent, preserving health and increasing glucose production.

As far as it is known, CG has not been studied separately from the dietary ingredients in the feedlot and in pre-slaughter lairage. The hypothesis tested in this study is that CG improves the performance and carcass and meat characteristics of goats. Moreover, when supplied in pre-slaughter lairage, it improves animal welfare and contributes to improve carcass and meat traits.

\section{Material and Methods}

The procedures adopted in this experiment were approved by the local Ethics Committee in Animal Experimentation and Welfare (CEEBEA) (case no. 093/2016). The experiment was performed in Janaúba, Minas Gerais, Brazil, located at $15^{\circ} 43^{\prime} 47^{\prime \prime} \mathrm{S}$ latitude, $43^{\circ} 19^{\prime} 18^{\prime \prime} \mathrm{W}$ longitude, and of $516 \mathrm{~m}$ altitude. 
The study involved 28 uncastrated male goats originating from a cross between Boer breed and mixed-breed animals, with an average initial weight of $16.96 \pm 1.66 \mathrm{~kg}$ and an average age of 90 days. Goats were distributed in a $2 \times 2$ factorial scheme in completely randomized design (place - feedlot or slaughterhouse; and food - water or CG) with seven replicates. In the feedlot, CG was supplied separately from the other ingredients. In the slaughterhouse, CG was provided during the $12 \mathrm{~h}$ that the animals remained in the stalls.

Animals were housed in individual $1.5-\mathrm{m}^{2}$ stalls equipped with feeders, drinkers, and wood shavings beds. The experimental period in the feedlot was 74 days, the first 18 days used for adaptation to the diets and facilities.

In the feedlot, two diets were formulated with a 40:60 roughage:concentrate ratio (Tables 1 and 2).

The crude glycerin, obtained from vegetable oil, was donated by the Petrobras Bicombustível S.A. industry (Montes Claros, MG, Brazil). The proportion of this ingredient in the diet was set at $96.90 \mathrm{~g} \mathrm{~kg}^{-1}$ of the total DM. This value was pre-fixed based on information from the scientific literature in which authors concluded that this rate did not change the intake or nutrient digestibility of goat and sheep diets (Gunn et al., 2010; Borges et al., 2013; Chanjula et al., 2014a; Silva et al., 2018). Diets were formulated to meet the requirements of crude protein and metabolizable energy and provide a gain of $200 \mathrm{~g}^{\text {day }}{ }^{-1}$ during the feedlot period, following the NRC (2007). Concentrate and forage were supplied twice a day, at 07:00 and 16:00 h. Crude glycerin was provided to the animals in a separate drinker, in its entirety, in the morning.

Table 1 - Compositions of the experimental diets $\left(\mathrm{g} \mathrm{kg}^{-1}\right.$ of dry matter)

\begin{tabular}{lcc}
\hline & Control & Glycerin \\
\hline Ingredient & & \\
$\quad$ Tifton hay 85 & 391.10 & 420.50 \\
Corn meal & 374.60 & 221.30 \\
Extruded soybean & 203.30 & 230.60 \\
Mineral salt & 24.70 & 24.70 \\
Calcitic limestone & 6.20 & 5.90 \\
Crude glycerin & - & 96.90 \\
Chemical composition & & \\
Dry matter & 879.90 & 856.00 \\
Crude protein & 145.50 & 158.70 \\
Ether extract & 14.50 & 18.50 \\
Neutral detergent fiber & 411.50 & 343.20 \\
Total carbohydrates & 614.20 & 598.70 \\
Non-fibrous carbohydrates & 202.60 & 235.50 \\
Glycerol & & 89.10 \\
\hline
\end{tabular}

${ }^{1}$ Guaranteed levels per kg product: Ca, $30 \mathrm{~g} ; \mathrm{P}, 21 \mathrm{~g} ; \mathrm{S}, 31 \mathrm{~g} ; \mathrm{Na}, 78 \mathrm{~g} ; \mathrm{Mg}, 4 \mathrm{~g} ; \mathrm{Zn}$, $600 \mathrm{mg}$; F, $210 \mathrm{mg}$; Mn, $200 \mathrm{mg}$; Fe, $300 \mathrm{mg}$; Se, $1.5 \mathrm{mg}$; Cu, $35 \mathrm{mg}$; Cr, $3.5 \mathrm{mg}$; Mo, $45 \mathrm{mg}$; I, $8 \mathrm{mg}$; Co, $1.8 \mathrm{mg}$.
Animals had water available ad libitum. Adjustments were made to the diet by weighing the orts of all feedstuffs, including $\mathrm{CG}$; these orts were fixed at $10 \%$ of the total amount offered. Feed intake was determined by subtracting the daily orts from the total provided.

Samples of the diet of each animal were collected for later chemical analyses of DM, ash, ether extract, and crude protein contents of orts from forage and concentrate, following the methodology proposed by AOAC (1995). Neutral detergent fiber corrected for ash and crude protein was obtained by following the recommendations of Detmann et al. (2012). Total carbohydrates were estimated using the equation proposed by Sniffen et al. (1992). To estimate the non-fibrous carbohydrates, we employed the equation proposed by the NRC (2001). The crude protein, ash, ether extract, and DM contents in the CG were obtained by the above-described procedures in analyses of the feeds. Glycerol and methanol contents were obtained by gas chromatography with a FID CG 17A detector (Shimadzu, Kyoto, Japan).

Animals were weighed at the end of the adaptation period and at the end of the feedlot stage, after feed deprivation for $16 \mathrm{~h}$. With these data, we determined their average daily weight gain and feed conversion.

In the feedlot, the animals were subjected to behavioral assessments for four 24-h periods by visual observation of their feeding behavior, which took place at 5-min intervals (Mezzalira et al., 2011). The following behavioral variables were studied: feeding (concentrate, roughage, or CG intakes), water intake, rumination, and idle (Azevedo et al., 2013).

At the end of the feedlot period, animals were deprived of solid diets for $16 \mathrm{~h}$. Subsequently, they were transported to the slaughterhouse over a distance of $311 \mathrm{~km}$. Goats were loaded into the vehicle, transported, and unloaded as recommended by Costa et al. (2008).

Table 2 - Analysis of the concentrate, Tifton 85 hay, and crude glycerin $\left(\mathrm{g} \mathrm{kg}^{-1}\right.$ of dry matter)

\begin{tabular}{lcccc}
\hline Composition & $\begin{array}{c}\text { Control } \\
\text { concentrate }\end{array}$ & $\begin{array}{c}\text { Glycerin } \\
\text { concentrate }\end{array}$ & Hay & $\begin{array}{c}\text { Crude } \\
\text { glycerin }\end{array}$ \\
\hline Dry matter & 926.90 & 926.50 & 807.30 & 707.50 \\
Crude protein & 215.83 & 270.80 & 102.40 & 1.40 \\
Ether extract & 30.96 & 27.42 & 18.60 & 1.37 \\
Minerals & 78.97 & 97.61 & 39.00 & 66.00 \\
Neutral detergent fiber & 136.23 & 135.89 & 598.90 & 0.00 \\
Total carbohydrates & 660.43 & 590.72 & 715.70 & 917.20 \\
Non-fibrous & 530.36 & 459.42 & 116.80 & 917.00 \\
carbohydrates & & & & \\
Glycerol & - & - & - & 916.20 \\
Methanol & - & - & - & 5.00 \\
Density $\left(\mathrm{g} \mathrm{mL}^{-1}\right)$ & - & - & - & 1.23 \\
\hline
\end{tabular}


In the slaughterhouse, as in the feedlot, animals were distributed individually into groups of animals that received CG and water and animals that received only water. The amount of CG provided per animal was $0.970 \mathrm{~kg}$. Water and CG were available to the animals until immediately before slaughter. Animals were filmed during the pre-slaughter lairage to measure the time the goats spent lying (lateral or ventral recumbency), according to methodology proposed by Silva et al. (2017). Prior to slaughter, goats had their blood drawn by jugular venipuncture into Vacutainer ${ }^{\circledR}$ tubes (BD Diagnostics, São Paulo, Brazil). Three tubes were collected: one with anticoagulant (EDTA), one containing potassium fluoride, and another without anticoagulant. The mean corpuscular volume was calculated by the formula of Wintrobe (Birgel, 1982). Total protein, albumin, creatine kinase, urea, and glucose values were measured in a spectrophotometer, using commercial kits (Doles ${ }^{\mathbb{R}}$ ). For analysis of hemoglobin and non-esterified fatty acids (NEFA), we used the Bioclin ${ }^{\circledR}$ kit and the Randox ${ }^{\circledR}$ kit, respectively. For the chemical analysis of cortisol, the chemiluminescence method was applied.

Slaughter commenced $12 \mathrm{~h}$ after the animals arrived at the slaughterhouse. Animals were stunned by electronarcosis, consisting of two electrodes placed on their head, which was immediately followed by bleeding in accordance with the Brazilian Federal Meat Inspection Regulations (Brasil, 2017).

Hot carcasses were weighed, washed, and taken to a cooling chamber with a temperature ranging from 2 to $4{ }^{\circ} \mathrm{C}$ for $24 \mathrm{~h}$. After cooling, carcasses were weighed again, and the ultimate $\mathrm{pH}$ was measured in the loin (LM thoracics et lumborum), as described by Pearce et al. (2010), using a portable $\mathrm{pH}$ meter. Carcass cuts were obtained in leg, loin, rib, and shoulder. A $10-\mathrm{cm}$ section of deboned longissimus muscle was removed from the carcass after $24 \mathrm{~h}$ of cooling. Meat color, conductivity, water loss by cooking, water holding capacity, and shear force were assessed on this portion of the loin.

Lightness $\left(\mathrm{L}^{*}\right)$, redness $\left(\mathrm{a}^{*}\right)$, and yellowness $\left(\mathrm{b}^{*}\right)$ values were measured according to the description of Devine et al. (2002) using the Hunter lab Miniscan model Miniscan EZ. The conductivity was measured using the Tec-3MP Tecnal instrument.

To determine water loss by cooking, meat was weighed and placed on an electric grill. Cooking was made with cuts of the loin wrapped in aluminum foil. When the temperature at the coldest point on the steaks reached $40{ }^{\circ} \mathrm{C}$, they were turned over, and the other side was grilled until reaching $71{ }^{\circ} \mathrm{C}$. Meat sections were then cooled to room temperature and weighed again (Ramos and Gomide, 2007).
Three cylindrical samples were taken from the meat sections that underwent cooking. Samples of $1.27 \mathrm{~cm}$ in diameter were used to perform the objective analysis of shear force, which was measured using a Warner-Bratzler type device (Wheeler et al., 2001).

The part of the raw longissimus muscle that remained after removing the steaks for cooking was used to evaluate the water holding capacity. These samples were subjected to centrifugation (4 $\mathrm{min} / 1500 \mathrm{rpm})$ and placed in an oven $\left(18 \mathrm{~h} / 70^{\circ} \mathrm{C}\right)$. The water holding capacity was calculated by the difference in weight (Nakamura and Katoh, 1981).

When significant $(\mathrm{P}<0.05)$, the dependent variables related to performance, carcass characteristics, and meat quality traits were adjusted as a function of the co-variable initial body weight. For the physiological variables, the respective co-variables corresponded to the measurements performed at the start of the feedlot period. In the case of variables measured only in the feedlot, means were compared by the $t$ test $(\mathrm{P}<0.05)$. For the variables lying, water intake, and crude glycerin intake, which were determined at the slaughterhouse, the assumptions of normality for the residuals and homogeneity of variance were not accepted. Therefore, the Kruskal-Wallis test was applied for the lying and water intake variables, while the Mann-Whitney was applied for crude glycerin intake $(\mathrm{P}<0.05)$. The physiological variables and the carcass and meat characteristics were analyzed using the procedure of model with fixed effects. In this model, the main effects were the feedlot, pre-slaughter lairage, and their interaction. After the analysis of variance, means were compared by the Student-Newman-Keuls (SNK) test, in case the interaction was significant $(\mathrm{P}<0.05)$.

The mathematical model used was:

$$
\mathrm{y}_{\mathrm{ijk}}=\mu+\alpha_{\mathrm{i}}+\beta_{\mathrm{j}}+\alpha_{\mathrm{i}} \beta_{\mathrm{j}}+\mathrm{e}_{\mathrm{ijk}} \text {, }
$$

in which $\mathrm{y}_{\mathrm{ijk}}=$ observed value of the variable that received CG in feedlot $i$, that received $C G$ in slaughterhouse $j$, and repetition $\mathrm{k} ; \mu=$ overall mean; $\alpha_{i}=$ feedlot - control diet or diet with $\mathrm{CG} ; \beta_{\mathrm{j}}=$ slaughterhouse - water or CG; $\alpha_{\mathrm{i}} \beta_{\mathrm{j}}=$ interaction effect; and $\mathrm{e}_{\mathrm{ijk}}=$ random error associated with each observation.

\section{Results}

The intakes of DM, crude protein, ether extract, mineral matter, neutral detergent indigestible fiber, organic matter, and total carbohydrates were lower for animals that ingested CG (Table 3). Goats that received CG also showed lower weight gain and body weight and same feed conversion than the animals in the control group. The time spent feeding, ruminating, ingesting water, and idling was 
similar between animals with or without CG inclusion in the diets. In pre-slaughter lairage, there was no influence of the $\mathrm{CG}$ availability on the time the goats spent lying (Table 4). Water and CG intakes were also not changed by the supply of CG.

There was no interaction between feedlot and preslaughter lairage on the studied physiological parameters of goats. In the feedlot, animals that consumed CG displayed lower albumin levels (Table 5); the other afore-mentioned

Table 3 - Nutrient intake, performance, and ingestive behavior of goats finished with diets with or without crude glycerin

\begin{tabular}{lcccc}
\hline Item & Control & Glycerin & SE & P-value \\
\hline${\text { Intake }\left(\mathrm{g} \mathrm{day}^{-1}\right)}$ Dry matter & 889.93 & 677.41 & 35.50 & 0.001 \\
$\quad$ Crude protein & 164.98 & 136.59 & 6.75 & 0.034 \\
Ether extract & 28.44 & 19.55 & 1.24 & 0.000 \\
Neutral detergent fiber & 412.39 & 265.66 & 20.42 & 0.000 \\
Ash & 47.84 & 37.34 & 1.90 & 0.004 \\
Organic matter & 842.09 & 640.07 & 33.60 & 0.001 \\
Total carbohydrate & 430.20 & 279.71 & 20.96 & 0.000 \\
$\quad$ Non-fiber carbohydrates & 538.65 & 359.34 & 23.98 & 0.000 \\
Performance & & & & \\
Average daily gain $(\mathrm{g})$ & 214.88 & 156.62 & 6.80 & 0.000 \\
Feed conversion & 4.18 & 4.45 & 0.19 & 0.474 \\
$\quad$ Final body weight $(\mathrm{kg})$ & 29.92 & 26.87 & 0.68 & 0.005 \\
Ingestive behavior $\left(\mathrm{h} \mathrm{day}{ }^{-1}\right)$ & & & & \\
Feeding & 3.60 & 3.75 & 0.17 & 0.665 \\
Ruminating & 6.59 & 5.94 & 0.60 & 0.166 \\
Water intake & 0.18 & 0.14 & 0.03 & 0.269 \\
Idle & 13.62 & 14.17 & 0.37 & 0.316 \\
\hline
\end{tabular}

SE - standard error. variables remained similar. In pre-slaughter lairage, these variables were not different between animals that received CG and those that did not.

Cortisol concentration of kids did not differ in the feedlot. In pre-slaughter lairage, goats consuming $\mathrm{CG}$ presented lower levels for this variable. Glucose, total protein, urea, and NEFA concentrations of goats were similar.

In the feedlot, the carcass weights and yields of animals were lower for the group consuming CG (Table 6). The weights of the cuts (leg, ribs, and shoulder) were also higher in goats that did not receive the ingredient in the feedlot. The loin-eye area of goats showed no alteration by the supply of CG. In pre-slaughter lairage, in turn, no effect of CG inclusion was detected for the carcass characteristics and weights of cuts.

The ultimate $\mathrm{pH}$ values of carcasses of kids were similar in goats that received $\mathrm{CG}$ and those that did not. Lightness (Hunter $\mathrm{L}^{*}$ ) and conductivity of the meat from goats that consumed CG only in the feedlot was lower. The CG intake of goats in the feedlot and pre-slaughter lairage periods caused no changes in water-holding capacity, cooking loss, or shear force of meat.

\section{Discussion}

Goats preferred the solid portion of the diet over the $\mathrm{CG}$, which directly influenced the DM intake. Unlike the present findings, Chanjula et al. (2014b) evaluated the inclusion of glycerin in goat diets at levels of up to $200 \mathrm{~g} \mathrm{~kg}^{-1}$

Table 4 - Water intake $(\mathrm{kg})$, crude glycerin intake $(\mathrm{g})$, and lying behavior (min) of goats during pre-slaughter lairage

\begin{tabular}{|c|c|c|c|c|c|c|c|}
\hline \multirow{2}{*}{ Item } & \multicolumn{4}{|c|}{ Treatment } & \multicolumn{2}{|c|}{ Percentile } & \multirow{2}{*}{ P-value } \\
\hline & $\mathrm{CG} / \mathrm{CG}$ & $\mathrm{CG} / \mathrm{W}$ & $\mathrm{W} / \mathrm{CG}$ & $\mathrm{W} / \mathrm{W}$ & 25 th & 75th & \\
\hline Water & 2.36 & 1.40 & 1.77 & 2.43 & 0.47 & 3.21 & 0.990 \\
\hline Glycerin & 460.14 & - & 64.61 & - & 39.29 & 537.97 & 0.480 \\
\hline Lying behavior & 497.00 & 574.00 & 457.00 & 509.00 & 423.00 & 623.00 & 0.160 \\
\hline
\end{tabular}

Treatments (feedlot/pre-slaughter): CG/CG - glycerin available/glycerin available; CG/W - glycerin available/glycerin unavailable; W/CG - glycerin unavailable/glycerin available W/W - glycerin unavailable/glycerin unavailable.

Table 5 - Physiological parameters of goats fed crude glycerin during feedlot and pre-slaughter lairage

\begin{tabular}{|c|c|c|c|c|c|c|c|c|}
\hline \multirow{2}{*}{ Item } & \multicolumn{2}{|c|}{ Feedlot (F) } & \multicolumn{2}{|c|}{ Pre-slaughter $(\mathrm{P})$} & \multirow{2}{*}{ SE } & \multicolumn{3}{|c|}{ P-value } \\
\hline & Glycerin & Control & Glycerin & Control & & $\mathrm{F}$ & $\mathrm{P}$ & $\mathrm{F} \times \mathrm{P}$ \\
\hline$\overline{\mathrm{MCV}}(\mathrm{fL})$ & 38.27 & 36.84 & 36.22 & 38.86 & 2.55 & 0.701 & 0.478 & 0.688 \\
\hline Glucose $\left(\mathrm{mg} \mathrm{dL}^{-1}\right)$ & 78.92 & 79.85 & 78.01 & 80.76 & 1.98 & 0.702 & 0.149 & 0.087 \\
\hline $\operatorname{Urea}\left(\mathrm{mg} \mathrm{dL}^{-1}\right)$ & 72.89 & 76.83 & 71.09 & 78.63 & 3.37 & 0.412 & 0.140 & 0.053 \\
\hline Albumin $\left(\mathrm{g} \mathrm{L}^{-1}\right)$ & 24.40 & 26.70 & 25.70 & 25.30 & 0.07 & 0.037 & 0.827 & 0.330 \\
\hline Total protein $\left(\mathrm{g} \mathrm{L}^{-1}\right)$ & 69.20 & 69.50 & 67.30 & 71.40 & 0.17 & 1.000 & 0.090 & 0.985 \\
\hline Cortisol $\left(\mathrm{ng} \mathrm{mL}^{-1}\right)$ & 7.50 & 6.40 & 5.50 & 8.40 & 0.06 & 0.344 & 0.003 & 0.320 \\
\hline
\end{tabular}

MCV - mean corpuscular volume; NEFA - non-esterified fatty acids; SE - standard error. 
Table 6 - Carcass and meat characteristics of goats fed crude glycerin during feedlot and pre-slaughter lairage

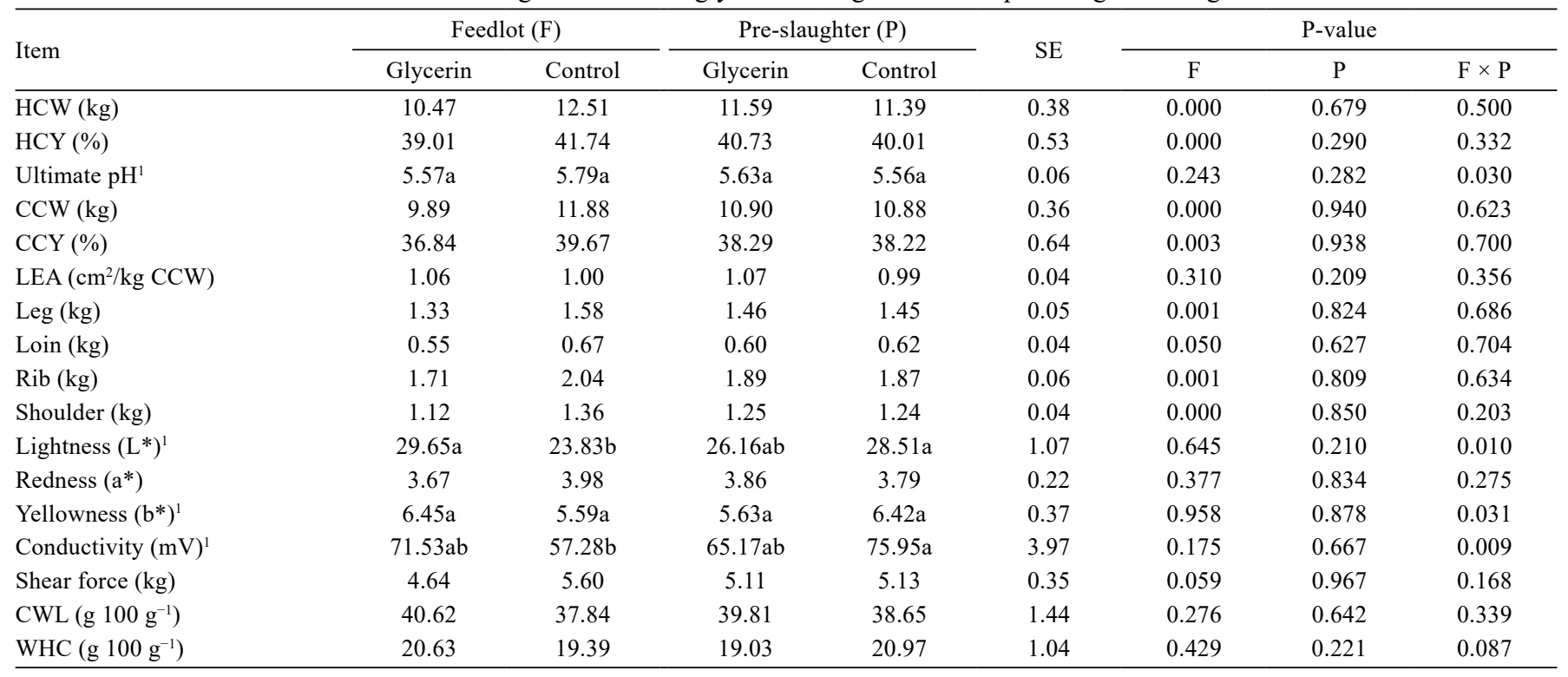

HCW - hot carcass weight; HCY - hot carcass yield; CCW - cold carcass weight; CCY - cold carcass yield; LEA - loin-eye area; CWL - cooking weight loss; WHC - water holding capacity; SE - standard error.

${ }_{1}^{1}$ Treatments (feedlot/slaughterhouse): glycerin/glycerin, glycerin/water, water/glycerin, and control (water/water), respectively.

Means in the same line with different letters are different $(\mathrm{P}<0.05)$.

DM and reported no alterations in animal growth-related parameters.

The decreased DM intake in the diet with CG led to a lower nutrient intake. At the same time, worse results for weight gain and body weight were found in this study, without interfering with feed conversion. Gomes et al. (2011) found no differences in DM intake, feed conversion, daily weight gain, or body weight with glycerin inclusion $\left(300 \mathrm{~g} \mathrm{~kg}^{-1} \mathrm{DM}\right)$ in the diet for lambs. Unlike the present work, the afore-mentioned authors mixed CG with other diet ingredients, which was the possible reason for the different results. The greater acceptability of soybean and corn would possibly increase CG intake of goats, if these ingredients were mixed.

The similar results for the feeding behavior-related variables are likely associated with the similar chemical composition of the diets, which were calculated to be isoenergetic and isonitrogenous and to have the same proportion of neutral detergent fiber (Table 1). According to Carvalho et al. (2011), the chemical composition of the feed, especially in terms of neutral detergent fiber contents, can directly influence the feeding behavior of ruminants, since this component is the main factor interfering with the rumen functioning.

Contrasting with this experiment, in relation to water and CG intakes, Pethick et al. (2000) reported that sheep fed a mixture of glycerol and propylene glycol had their water intake doubled for a period of one to two days.

Concentrations of albumin, total proteins, urea, and mean corpuscular volume are used for the evaluation of the hydration status (Thrall et al., 2015). Although albumin concentrations indicate a higher water intake for animals that consumed CG, no differences were found in the waterintake behavior (Table 3). According to Parker et al. (2007), the prophylactic treatment with glycerol in sheep results in over-hydration.

Cortisol is commonly used to evaluate experimental situations involving animal welfare, as indicator of fear and excitement (Broom and Fraser, 2010). Stress stimulates the hypothalamic-adrenal cortex axis with subsequent release of cortisol (Zimerman et al., 2013, Chulayo et al., 2016). Cortisol in turn stimulates gluconeogenesis from amino acids and glycerol and elevates the blood NEFA concentrations (Lehninger, 2006). High concentrations of cortisol, in association with hunger due to long periods of fasting in pre-slaughter, lead to an increase in protein catabolism (Kannan et al., 2000; Zimerman et al., 2013). Therefore, the greater stimulation of gluconeogenesis in the treatment without CG might have resulted in similar glucose concentrations between the treatments. However, no greater mobilization of glucogenic amino acids or triglycerides was verified in the treatment without CG because the total protein, urea, and NEFA concentrations were similar between the treatments. Because there was no interaction between feedlot and pre-slaughter lairage, the benefit from the use of CG in relation to the cortisol concentration in pre-slaughter does not depend on the previous supply of this ingredient in the feedlot.

Since the performance of animals that consumed CG in feedlot was lower (Table 3), the carcass characteristics 
and weights of the cuts also had quantitative losses, as also reported by Lage et al. (2014). Observing the result for loin-eye area, it was noted that the amount of edible portion of the carcasses remained similar between the treatments. Carvalho et al. (2015) also found that carcass weight decreased as CG was included in the diet (up to

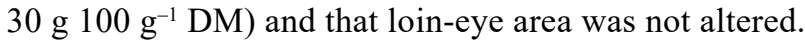

For Aberle et al. (2001), the ultimate $\mathrm{pH}$ in the muscle of animals not subjected to starvation or exercise prior to slaughter is below 5.7. Because the performance obtained with the treatments including the ingredient was inferior (Table 3), one can hypothesize that CG intake in lairage mitigates the problem of animals consuming it in the feedlot, given that lightness was higher in the other treatments. Conductivity followed the same pattern as lightness. Conductivity and lightness had an inverse relationship with the final $\mathrm{pH}$ (Lawrie, 2005, Velarde et al., 2000), which makes this result coherent. Likewise, Borghi et al. (2016) found no changes in water holding capacity, cooking losses, and shear force in meat of lambs fed diets containing different levels of crude glycerin. Similarly, Lage et al. (2014) observed no changes in ultimate $\mathrm{pH}$, cooking losses, and shear force in meat of lambs fed diets containing different levels of crude glycerin. The average values for shear force in all treatments of this study were considered by Souza et al. (2004) as the upper limit for considering the meat as tender. Overall, the meat quality traits of the goats studied here were similar to those found in other studies with crossbred goats and were within the range associated with good quality (Beserra et al., 2001; Borges et al., 2006; Monte et al., 2007).

\section{Conclusions}

Crude glycerin provided separately from the other dietary ingredients to goats in the feedlot period negatively affects their performance and carcass characteristics, without changing the meat quality. In pre-slaughter lairage, crude glycerin reduces the cortisol levels, but does not alter behavior parameters or carcass and meat characteristics.

\section{Acknowledgments}

The authors thank the Fundação de Amparo à Pesquisa de Minas Gerais (FAPEMIG), for financing the project (CVZ-APQ-02716-14), and the Conselho Nacional de Desenvolvimento Científico e Tecnológico (CNPq), the Coordenação de Aperfeiçoamento de Pessoal de Nível Superior (CAPES), and FAPEMIG, for the scholarships and research grants granted to the authors.

\section{References}

Aberle, E. D.; Forrest, J. C.; Gerrard, D. E. and Mills, E. W. 2001. Principles of meat science. 4th ed. Kendall/Hunt Publ. Co., Duboque, IO.

ANP - Agência Nacional do Petróleo. 2016. Anuário Estatístico Brasileiro do Petróleo, Gás Natural e Biocombustíveies. ANP, Rio de Janeiro, RJ.

AOAC - Association of Official Analytical Chemists. 1995. Official methods of analysis. 16th ed, 2 vols. AOAC International, Washington, DC.

Azevedo, R. A.; Rufino, L. M. A.; Santos, A. C. R.; Ribeiro Júnior, C. S.; Rodriguez, N. M. and Geraseev, L. C. 2013. Comportamento ingestivo de cordeiros alimentados com torta de macaúba. Arquivo Brasileiro de Medicina Veterinária e Zootecnia 65:490-496. https://doi.org/10.1590/S0102-09352013000200027

Beserra, F. J.; Moura, R. P.; Da Silva, E. M. C. and Madruga, M. S. 2001. Características químicas e físico-químicas da carne de caprinos SRD com diferentes pesos de abate. Revista Tecnologia Carnes 3:1-6.

Birgel, E. H. 1982. Hematologia clínica veterinária. p.2-34. In: Patologia clínica veterinária. Birgel, E. H. and Benesi, F. J., eds. Sociedade Paulista de Medicina Veterinária, São Paulo, SP.

Borges, G. D. S.; Macedo, V. P.; Maeda, E. M.; Silveira, A. L. F. and Castro, J. M. 2013. Digestibilidade de dietas contendo níveis de glicerina bruta em substituição ao milho fornecidas a caprinos de corte. Synergismus scyentifica UTFPR 8:1-3.

Borges, A. D. S.; Zapata, J. F. F.; Garruti, D. D. S. E. A. T.; Rodrigues, M. D. C. P.; Freitas, E. R. and Pereira, A. L. F. 2006. Medições instrumentais e sensoriais de dureza e suculência na carne caprina. Ciência e Tecnologia de Alimentos 26:891-896. https://doi.org/10.1590/S0101-20612006000400028

Borghi, T. H.; Silva Sobrinho; A. G. D.; Zeola, N. M. B. L.; Almeida, F. A. D.; Cirne, L. G. A. and Lima, A. R. C. 2016. Dietary glycerin does not affect meat quality of Ile de France lambs. Revista Brasileira de Zootecnia 45:554-562. https://doi.org/10.1590/s1806-92902016000900008

Brasil. 2017. Ministério da Agricultura e do Abastecimento. Departamento de Inspeção de Produtos de Origem Animal. Divisão de Normas Técnicas. Regulamento da inspeção industrial e sanitária de produtos de origem animal: aprovado pelo Decreto $\mathrm{n}^{\circ}$ 9.013, de 2017. Ministério da Agricultura, Brasília, DF.

Broom, D. M. and Fraser, A. F. 2010. Comportamento e bem-estar dos animais domésticos. $4^{\mathrm{a}}$ ed. Manole, São Paulo, SP.

Carvalho, G. G. P. D.; Garcia, R.; Pires, A. J. V.; Detmann, E.; Ribeiro, L. S. O.; Chagas, D. M. T.; Silva, R. R. and Pinho, B. D. 2011. Comportamento ingestivo em caprinos alimentados com dietas contendo cana-de-açúcar tratada com óxido de cálcio. Revista Brasileira de Zootecnia 40:1767-1773. https://doi.org/10.1590/S1516-35982011000800021

Carvalho, V. B.; Leite, R. F.; Almeida, M. T. C.; Paschoaloto, J. R.; Carvalho, E. B.; Lanna, D. P. D.; Perez, H. L.; Van Cleef, E. H. C. B.; Homem Junior, A. C. and Ezequiel, J. M. B. 2015. Carcass characteristics and meat quality of lambs fed high concentrations of crude glycerin in low-starch diets. Meat Science 110:285-292. https://doi.org/10.1016/j.meatsci.2015.08.001

Chanjula, P.; Pakdeechanuan, P. and Wattanasit, S. 2014a. Effects of dietary crude glycerin supplementation on nutrient digestibility, ruminal fermentation, blood metabolites, and nitrogen balance of goats. Asian-Australasian Journal of Animal Sciences 27:365-374. https://doi.org/10.5713/ajas.2013.13494

Chanjula, P.; Pakdeechanuan, P. and Wattanasit, S. 2014b. Performance and carcass traits of fattening goats fed crude glycerin in the diet. p.10-14. In: Proceedings of the 16th AAAP Animal Science Congress, Yogvakarta, Java.

Chulayo, A. Y.; Bradley, G. and Muchenje, V. 2016. Effects of transport distance, lairage time and stunning efficiency on cortisol, glucose, 
HSPA1A and how they relate with meat quality in cattle. Meat Science 117:89-96. https://doi.org/10.1016/j.meatsci.2016.03.001

Costa, M. J. R. P.; Spironelli, A. L. G. and Quintiliano, M. H. 2008. Boas práticas de manejo: embarque. Ministério da Agricultura, Pecuária e Abastecimento, Brasília, DF.

Del Campo, M. 2016. Bem-estar animal: Sistemas de produção, práticas de manejo e qualidade da carne. p.94-107. In: Bem estar animal como valor agregado nas cadeias produtivas de carnes. Paranhos da Costa, M. J. R. and Sant'Anna, A. C., eds. Funep, Jaboticabal, SP.

Detmann, E.; Souza, M. A.; Valadares Filho, S. C.; Queiroz, A. C.; Berchielli, T. T.; Saliba, E. O. S.; Cabral, L. S.; Pina, D. S.; Ladeira, M. M. and Azevêdo, J. A. G. 2012. Métodos para análise de alimentos. Suprema, Visconde do Rio Branco.

Devine, C. E.; Payne, S. R.; Peachey, B. M.; Lowe, T. E.; Ingram, J. R. and Cook, C. J. 2002. High and low rigor temperature effects on sheep meat tenderness and ageing. Meat Science 60:141-146. https://doi.org/10.1016/S0309-1740(01)00115-2

Donkin, S. S.; Koser, S. L.; White, H. M.; Doane, P. H. and Cecava, M. J. 2009. Feeding value of glycerol as a replacement for corn grain in rations fed to lactating dairy cows. Journal of Dairy Science 92:5111-5119. https://doi.org/10.3168/jds.2009-2201

Egea, M.; Linares, M. B.; Hernández, F.; Madrid, J. and Garrido, M. D. 2015. Pre-slaughter administration of glycerol as carbohydrate precursor and osmotic agent to improve carcass and beef quality. Livestock Science 182:1-7. https://doi.org/10.1016/j.livsci.2015.10.011

Gomes, M. A. B.; Moraes, G. V. D.; Mataveli, M.; Macedo, F. D. A. F. D.; Carneiro, T. C. and Rossi, R. M. 2011. Performance and carcass characteristics of lambs fed on diets supplemented with glycerin from biodiesel production. Revista Brasileira de Zootecnia 40:2211-2219. https://doi.org/10.1590/S1516-35982011001000022

Gunn, P. J.; Neary, M. K.; Lemenager, R. P. and Lake, S. L. 2010. Effects of crude glycerin on performance and carcass characteristics of finishing wether lambs. Journal of Animal Science 88:1771-1776. https://doi.org/10.2527/jas.2009-2325

Kannan, G.; Terrill, T. H.; Kouakou, B.; Gazal, O. S.; Gelaye, S.; Amoah, E. A. and Samake, S. 2000. Transportation of goats: Effects on physiological stress responses and live weight loss. Journal of Animal Science 78:1450-1457. https://doi.org/10.2527/2000.7861450x

Lage, J. F.; Paulino, P. V. R.; Pereira, L. G. R.; Duarte, M. S.; Valadares Filho, S. C.; Oliveira, A. S.; Souza, N. K. P. and Lima, J. C. M. 2014. Carcass characteristics of feed lot lambs fed crude glycerin contaminated with high concentrations of crude fat. Meat Science 96:108-113. https://doi.org/10.1016/j.meatsci.2013.06.020

Lawrie, R. A. 2005. Ciência da carne. Artmed, Porto Alegre, RS.

Lehninger, A. L. 2006. Lehninger princípios de bioquímica. 4a ed. Sarvier, São Paulo.

Mezzalira, J. C.; Carvalho, P. C. F.; Fonseca, L.; Bremm, C.; Reffatti, M. V.; Poli, C. H. E. C. and Trindade, J. K. 2011. Aspectos metodológicos do comportamento ingestivo de bovinos em pastejo. Revista Brasileira de Zootecnia 40:1114-1120. https://doi.org/10.1590/S1516-35982011000500024

Monte, A. L. D. S.; Selaive-Villarroel, A. B.; Garruti, D. D. S. E. A. T.; Zapata, J. F. F. and Borges, A. S. 2007. Parâmetros físicos e sensoriais de qualidade da carne de cabritos mestiços de diferentes grupos genéticos. Ciência e Tecnologia de Alimentos. 27:233-238. https://doi.org/10.1590/S0101-20612007000200004

Nakamura, M. and Katoh, K. 1981. Influence of thawing methods on several properties of rabbit meat. Bulletin of Ishikawa Prefecture College of Agriculture (Japan) 11:45-49.

NRC - National Research Council. 2001. Nutritional requirements of dairy cattle. 7th ed. NRC National Academies, Washington, DC.
NRC - National Research Council. 2007. Nutritional requirements of small ruminants: sheep, goats, cervids, and new world camelids. National Academies, Washington, DC.

Parker, A. J.; Dobson, G. P. and Fitzpatrick, L. A. 2007. Physiological and metabolic effects of prophylactic treatment with the osmolytes glycerol and betaine on Bos indicus steers during long duration transportation. Journal of Animal Science 85:2916-2923. https://doi.org/10.2527/jas.2006-193

Parsons, G. L.; Shelor, M. K. and Drouillard, J. S. 2009. Performance and carcass traits of finishing heifers fed crude glycerin. Journal of Animal Science 87:653-657.https://doi.org/10.2527/jas.2008-1053

Pearce, K. L.; Van De Ven, R.; Mudford, C.; Warner, R. D.; HockingEdwards, J.; Jacob, R.; Pethick, D. W. and Hopkins, D. L. 2010. Case studies demonstrating the benefits on $\mathrm{pH}$ and temperature decline of optimising medium-voltage electrical stimulation of lamb carcasses. Animal Production Science 50:1107-1114. https://doi.org/10.1071/AN10114

Pellegrin, A. C. R. S.; Pires, C. C.; Carvalho, S.; Pacheco, P. S.; Pelegrini, L. F. V.; Griebler, L. and Venturini, R. S. 2012. Glicerina bruta no suplemento para cordeiros lactentes em pastejo de azevém. Ciência Rural 42:1477-1482.

Pethick, D. W.; Cummins, L.; Gardner, G. E.; Jacob, R. H.; Knee, B. W.; McDowell, M.; McIntyre, B. L.; Tudor, G.; Walker, P. J. and Warner, W. D. 2000. The regulation of glycogen level in the muscle of ruminants by nutrition. Proceedings of the New Zealand Society of Animal Production 60:94-98.

Ramos, E. M. and Gomide, L. A. 2007. Avaliação da qualidade de carnes: fundamento e metodologias. UFV, Viçosa, MG.

Silva, F. V.; Borges, I.; Lana, A. M. Q.; Borges, A. L. C. C.; Sá, H. C. M.; Silva, V. L.; Alves, L. R. N. and Souza, A. F. 2017. Bem-estar dos cordeiros submetidos ao transporte rodoviário e avaliação das carcaças e carnes. Pesquisa Veterinária Brasileira 37:630-636. https://doi.org/10.1590/s0100-736x2017000600017

Silva, F. V.; Borges, I.; Silva, V. L.; Lana, A. M. Q.; Borges, A. L. C. C.; Reis, S. T.; Araújo, A. R. and Matos, A. M. 2018. Performance and carcass characteristics of lambs fed a solution of crude glycerin during feedlot and pre-slaughter lairage. Revista Brasileira de Zootecnia 47:e20170032. https://doi.org/10.1590/rbz4720170032

Sniffen, C. J.; O’Connor, J. D. and Van Soest, P. J. 1992. A net carbohydrate and protein system for evaluating cattle diets. II. Carbohydrate and protein availability. Journal of Animal Science 70:3562-3577.

Souza, X. R.; Bressan, M. C.; Pérez, J. R. O.; Faria, P. B.; Vieira, J. O. and Kabeya, D. M. 2004. Efeitos do grupo genético, sexo e peso ao abate sobre as propriedades físico-químicas da carne de cordeiros em crescimento. Ciência e Tecnologia de Alimentos 24:543-549. https://doi.org/10.1590/S0101-20612004000400011

Terré, M.; Nudda, A. and Casado, P. 2011. The use of glycerine in rations for light lamb during the fattening period. Animal Feed Science and Technology 164:262-267. https://doi.org/10.1016/j.anifeedsci.2010.12.008

Thrall, M. A.; Weiser, G.; Allison, R. W. and Campbell, T. W. 2015. Hematologia e bioquímica clínica veterinária. 2a ed. Roca, São Paulo, SP.

Velarde, A.; Gispert, M.; Faucitano, L.; Manteca, X. and Diestre, A. 2000. The effect of stunning method on the incidence of PSE meat and haemorrhages in pork carcasses. Meat Science 55:309-314. https://doi.org/10.1016/S0309-1740(99)00158-8

Wheeler, T. L.; Shackelford, S. D. and Koohmaraie, M. 2001. Shear force procedures for meat tenderness measurement. Roman L. Hruska US Marc.USDA, Clay Center, NE.

Zimerman, M.; Domingo, E.; Grigioni, G.; Taddeo, H. and Willems, P. 2013. The effect of pre-slaughter stressors on physiological indicators and meat quality traits on Merino lambs. Small Ruminant Research 111:6-9. https://doi.org/10.1016/j.smallrumres.2012.12.018 